\title{
Knowledge, attitude and practice of pharmacists to pharmacovigilance and adverse drug reactions reporting process: a cross-sectional study in Kosovo
}

\author{
Selvete Shuleta Qehaja ${ }^{1}$, Zoran Sterjev ${ }^{2 *}$, Ljubica Shuturkova ${ }^{2}$, \\ Aleksandra Kapedanovska ${ }^{2}$, Zorica Naumovska ${ }^{2}$, Virtyte Krasniqi ${ }^{3}$, Erblin Elezi ${ }^{4}$ \\ ${ }^{I} N{ }^{l}$ Alma Mater Europaea Campus College "Rezonanca", \\ Glloku te Shelgjet "Veternik", 10000 Prishtina, Kosovo \\ ${ }^{2}$ Ss. Cyril and Methodius University in Skopje, Faculty of Pharmacy, \\ Majka Tereza 47, 1000 Skopje, North Macedonia \\ ${ }^{3}$ Kosovo Medicines Agency, Rrethi i spitalit (QKUK), 10000 Prishtina, Kosovo \\ ${ }^{4}$ Central Pharmacy - University Clinical Center, 10000 Prishtina, Kosovo
}

Received: June 2021; Accepted: July 2021

\begin{abstract}
Pharmacovigilance (PV) and drug safety monitoring have an essential role in protecting public health. A cross-sectional study evaluated pharmacist knowledge, attitude and practice toward PV and adverse drug reactions (ADRs) reporting. The structured validated questionnaire was distributed to 550 randomly selected pharmacists in the whole Kosovo region. 405 out of 550 pharmacists responded to the questionnaire. Most pharmacists have insufficient knowledge about pharmacovigilance and the ADRs reporting process. The main reasons for under-reporting were little knowledge of pharmacovigilance and adverse reporting process, lack of time, and lack of infrastructure. However, pharmacists showed a positive attitude and stated that they would practice pharmacovigilance if they receive the training. There is a necessity to intensify communication among all stakeholders involved in PV. In addition, continuous training and education are needed to increase pharmacist's awareness and knowledge of PV and their participation in the ADRs reporting process.
\end{abstract}

Keywords: Pharmacovigilance, adverse drug reaction, knowledge, attitude, practice, pharmacists, Kosovo

\section{Introduction}

Pharmacovigilance (PV) is the "science and activities relating to the detection, assessment, understanding, and prevention of adverse effects or any other drug-related problem" (WHO, 2002).

As stated by the International Pharmaceutical Federation (FIP), the "safety monitoring of medicines is an integral part of clinical practice" (FIP, 2006).

Kosovo is a lower-middle-income country with substantial economic growth over the last decade (The World Bank, 2019). Kosovo consists of seven districts (Prishtina/Pristina, Gjilan/Gnjilane, Gjakova/Djakovica, Peja/Peć, Mitrovica, Ferizaj/Uroševac and Prizren). The largest district is the Region of Prishtina, with Prishtina as the capital city, where is located the most significant number of pharmaceutical warehouses, pharmacies, healthcare hospitals, and representative offices of pharmaceutical companies.

PV Department within Kosovo Medicines Agency (KMA) has been established since 2006, and legal

\footnotetext{
$\bar{*}$ zost@ff.ukim.edu.mk
} 
provisions regarding $\mathrm{PV}$ have been updated according to the EU legislation (KMA, 2021). However, there is still a low number of reports on suspected adverse drug reactions (ADR) submitted by healthcare professionals, including pharmacists.

Olsson et al. (2010) found that the main obstacle in strengthening PV capacities in low- and middle-income countries was inadequately trained staff and local specialists. Furthermore, different studies showed (Elshafie et al., 2018; Wilson et al., 2020) that PV is still considered a low priority in developing countries. However, various issues raise concerns that increase systems' need to monitor post-marketing drug safety in these countries.

As emphasized by different authors, healthcare professionals require considerable knowledge and expertise in medication safety and should acquire a combination of training and research skills in medication safety (Najafi., 2018; Almandil., 2016).

Pharmacists, as healthcare professionals, play an essential role in drug safety monitoring and PV. The involvement of pharmacists in national spontaneous reporting systems for ADRs is significant for public health. Khalili et al. (2012) stated that when pharmacists have sufficient knowledge of the ADR reporting process, they can improve other healthcare professionals' knowledge about ADR reporting.

The studies in many countries show that the knowledge of pharmacists about PV and adverse drug reaction (ADR) reporting is poor, and there is a low reporting rate (Lee et al., 1994; Oreagba et al., 2011; Su et al., 2010; Toklu and Uysal., 2008; Vessal et al., 2009).

To our knowledge, until now in Kosovo, there have been no studies that evaluated pharmacists' knowledge, attitudes and practice regarding $\mathrm{PV}$ and the ADR reporting process. Therefore, the study aimed to assess pharmacists' knowledge, practice, attitude and perceived PV and ADRs reporting barriers.

\section{Materials and methods}

The cross-sectional study was performed in the whole Kosovo region. The study duration was between December 2018 - May 2019. In December 2018, there were 1049 registered pharmacists by the Pharmaceutical Chamber of Kosovo.

The questionnaire was distributed to 550 randomly selected pharmacists involved in community pharmacies, hospital pharmacies, pharmaceutical wholesalers, pharmaceutical industry, academia and governmental institutions. About 300 were in the Prishtina district, and 250 were in the remaining six other Kosovo districts. Thus, 405 out of 550 pharmacists responded to the questionnaire. The overall response rate was $73.64 \%$.

The questionnaire was adapted by referring to previous studies conducted in different countries. It was prepared to collect the information related to sociodemographic data, questions on knowledge, attitude, practice and barriers for reporting, and suggestions for improvement. (Ahmad et al., 2013; Ali et al., 2018; Amedome and Dadson., 2017; Li et al., 2018; Nisa et al., 2018; Prakasam et al., 2012; Suyagh et al., 2015).

The questionnaire's content validity was analyzed by distributing the questionnaire to ten community pharmacists, five hospital pharmacists, and ten pharmacists from academia, government, pharmaceutical companies, and pharmaceutical wholesalers. In addition, the most appropriate questions to Kosovo's circumstances were selected and translated into the Albanian language. Cronbach's $\alpha$ was calculated using the reliability scale and the overall $\alpha$ value was 0.896 .

The questionnaire consisted of pharmacist demographic data and questions that covered the following domains: (1) evaluation of pharmacist knowledge regarding PV and ADRs reporting, (2) pharmacist's attitude and practice toward ADRs reporting process, and (3) pharmacists' perceived barriers for reporting and suggestions to improve the PV system in Kosovo. In addition, it was one open-ended question regarding the minimum criteria of reporting.

The Pharmaceutical Chamber of Kosovo approved the study protocol. Pharmacists were given explanations about the objective of the study. The self-administered questionnaire was delivered only to pharmacists, who gave verbal consent to participate in the study. They were also assured that the questionnaire was confidential and that the results would be presented anonymously. Descriptive statistics (frequency and percentages; mean and standard deviation (SD)) was applied to summarize the data.

Data analyses were completed using SPSS.v.20 software (SPSS, Inc., Chicago, IL, USA), and an analysis of associations between variables using the Pearson ChiSquare test was carried out, and $p$ values $<0.05$ were considered statistically significant.

\section{Results}

The demographic data of the pharmacists who participated in the study are presented in Table 1 . The mean age of pharmacists was approximately 33.34 years (SD 8.028), and the average year of working experience was 2.66 years (SD 1.060). Thus, $32.1 \%$ of pharmacists had 6-10 years of experience. In this study, $67.9 \%$ of participants were community pharmacists, while $32.1 \%$ were engaged in positions unrelated to community pharmacy (hospital pharmacist and pharmacists working in pharmaceutical distribution, pharmaceutical industry, academia, and governmental institutions). Females accounted for $58.5 \%$ of pharmacists. In addition, 58\% of pharmacists were in the Prishtina district. 
Table 1. Socio-demographic characteristics of the pharmacists $(\mathrm{N}=405)$

\begin{tabular}{|c|c|c|}
\hline Characteristics & Number of participants (N) & $\%$ \\
\hline \multicolumn{3}{|l|}{ Gender } \\
\hline Male & 168 & 41.5 \\
\hline Female & 237 & 58.5 \\
\hline \multicolumn{3}{|l|}{ Age (Years) } \\
\hline $20-30$ & 167 & 41.2 \\
\hline $31-40$ & 168 & 45.9 \\
\hline $41-50$ & 33 & 8.1 \\
\hline $51-60$ & 16 & 4 \\
\hline $61-70$ & 3 & 0.7 \\
\hline \multicolumn{3}{|l|}{ Qualification } \\
\hline Graduated pharmacist & 355 & 87.7 \\
\hline $\begin{array}{l}\text { Other titles of pharmacy rather than a graduated } \\
\text { pharmacist }\end{array}$ & 50 & 12.3 \\
\hline \multicolumn{3}{|l|}{ Workplace } \\
\hline Community pharmacy & 275 & 67.9 \\
\hline $\begin{array}{l}\text { Other fields of pharmacy not related to community } \\
\text { pharmacy }\end{array}$ & 130 & 32.1 \\
\hline \multicolumn{3}{|l|}{ Districts } \\
\hline Prishtina district & 235 & 58 \\
\hline Other districts & 170 & 42 \\
\hline \multicolumn{3}{|l|}{ Working experience } \\
\hline Less than one year & 75 & 18.5 \\
\hline $1-5$ years & 93 & 23 \\
\hline $6-10$ years & 130 & 32.1 \\
\hline Over ten years & 107 & 26.4 \\
\hline
\end{tabular}

Abbreviations: $N$ - number; \% - percentage

Pharmacists' knowledge regarding pharmacovigilance and $A D R$ reporting process in Kosovo

This part of the questionnaire contained one openended question in which the pharmacists were demanded to indicate "minimum reporting criteria."

Of the responding pharmacists, $87.2 \%$ were familiar with the term PV, and $70.6 \%$ gave the correct definition of the ADR.

$73.1 \%$ of pharmacists stated that medicines placed on the market are not safe. Regarding their knowledge related to reporting, $77.8 \%$ of participants declared that they know the PV Department. However, it was found that pharmacists from other fields of pharmacy not associated with community pharmacy knew significantly more than community pharmacy pharmacists (presented in Table 2 and Table 3). In addition, $54.1 \%$ of pharmacists knew that there were reporting forms available, and the results also showed a significant difference between groups regarding their workplace (Table 3).

As shown in Table 2, 55.3\% stated that they knew where to take reporting forms, and it was a statistically significant difference with their workplace. 
Table 2. Responses to knowledge questions*

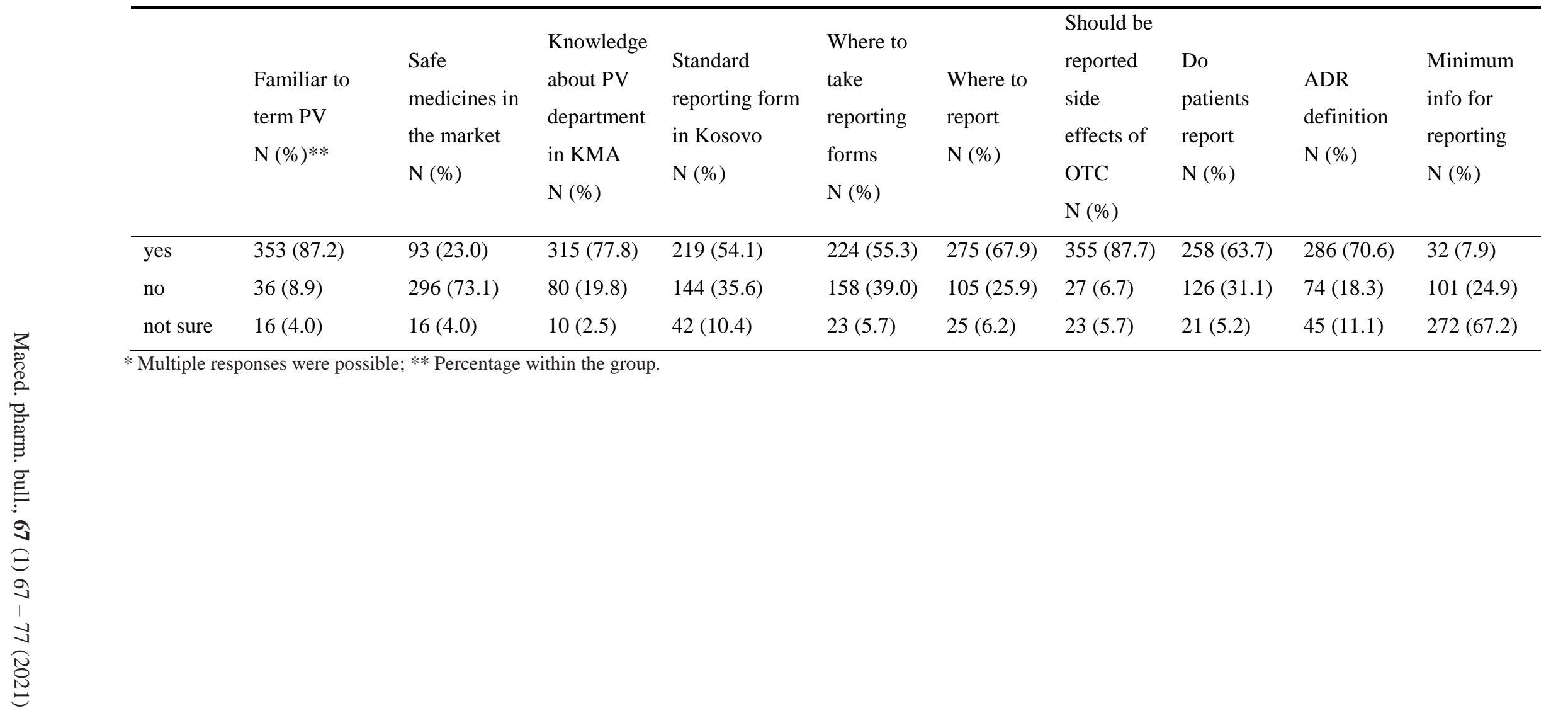


$67.9 \%$ of pharmacists knew where to report ADR, while pharmacists working in other fields of pharmacy not related to community pharmacy knew significantly more than their counterparts $(p<0.05)$ (Table 3$)$.

$87.7 \%$ of respondents stated that the side effects of OTC medicines should be reported. In a question regarding patient reports of ADRs, $63.7 \%$ of pharmacists answered that they receive patient complaints on side effects and community pharmacists had a statistically significantly higher percentage than their counterparts (Table 3). Of the 258 pharmacists who claimed to receive patient complaints, 60 of them declared that they rarely accept reports (one per year), 57 received reports one per month, and 27 received one report per week. However, although they declared that they receive reports, a small number of received reports by KMA shows that they are not implementing practically the reporting process.

In the open-ended question to indicate minimum reporting criteria, only $7.9 \%$ of respondents gave the correct answer, while $67.2 \%$ were unsure about the minimum reporting criteria. The results are presented in Table 2.

\section{Pharmacists' attitudes toward ADRs reporting}

$85.7 \%$ of pharmacists, as presented in Table 4 , stated that reporting of ADRs is their essential role and the same percentage also considers that there is a necessity to include PV in curricula. The vast majority of pharmacists $(83.7 \%)$ consider that new knowledge regarding PV needs to be updated. When asked whether community and hospital pharmacists should be the first reporting point, $80 \%$ of pharmacists answered positively, and $91.1 \%$ stated that reporting ADRs and monitoring would help patients. $86.7 \%$ consider that reporting ADRs should be obligatory, while $70.4 \%$ responded that reporting should be a professional obligation. The majority of pharmacists (81.7\%) declared that they would practice PV if they receive the training.

In general, younger pharmacists showed a significantly more positive attitude $(\mathrm{p}<0.05)$ compared to other subgroups (Table 5).

\section{Pharmacists' practice regarding pharmacovigilance ADRs reporting}

The data presented in Table 6 show that $77.3 \%$ of pharmacists rely on the internet/webpages, while $73.3 \%$ rely on patient information leaflets. $70.1 \%$ and $45.9 \%$ on reference books and medical journals, respectively. Only $39 \%$ of pharmacists rely on medical representatives, and $61.5 \%$ of respondents also declared KMA bulletins.

Table 3. Response differences between pharmacists depending on their workplace

\section{Workplace}

Questions

Community pharmacists $\mathrm{N}(\%)^{* *}$

$199(72.4 \%)$

$116(89.2 \%)$

Pharmacovigilance

$199(72.4 \%)$

Department in KMA

Knowledge about standard

reporting form in Kosovo

$122(44.4 \%)$

$97(74.6 \%)$

Knowledge on where to

take forms for reporting

$129(46.9 \%)$

$95(73.1 \%)$

ADRs

Knowledge where to report

$169(61.5 \%)$

$106(81.5 \%)$

Patients reporting an

adverse reaction? If yes,

$199(72.4 \%)$

$59(45.4 \%)$

how often?

Answer: yes, $p<0.05$; ** Percentage within the group. 
Table 4. Responses to attitude questions *

\begin{tabular}{|c|c|c|c|c|c|c|c|c|}
\hline & & & & Comm and & & & & \\
\hline & $\begin{array}{l}\text { Reporting is } \\
\text { an essential } \\
\text { role of } \\
\text { pharmacist } \\
\mathrm{N}(\%)^{* *}\end{array}$ & $\begin{array}{l}\text { PV to } \\
\text { include in } \\
\text { curricula } \\
\mathrm{N}(\%)\end{array}$ & $\begin{array}{l}\text { New } \\
\text { knowledge } \\
\text { to be } \\
\text { updated } \\
\mathrm{N}(\%)\end{array}$ & $\begin{array}{l}\text { hosp } \\
\text { pharmacist } \\
\text { first } \\
\text { reporting } \\
\text { point N } \\
(\%)\end{array}$ & $\begin{array}{l}\text { If trained, } \\
\text { will } \\
\text { practice } \\
\text { PV } \\
\mathrm{N}(\%)\end{array}$ & $\begin{array}{l}\text { Report and } \\
\text { monitor } \\
\text { will help } \\
\text { patients } \\
\mathrm{N}(\%)\end{array}$ & $\begin{array}{l}\text { Reporting } \\
\text { to be } \\
\text { obligative } \\
\mathrm{N}(\%)\end{array}$ & $\begin{array}{l}\text { Reporting to } \\
\text { be } \\
\text { professional } \\
\text { obligation } \\
\mathrm{N}(\%)\end{array}$ \\
\hline yes & 347 (85.7) & 347 (85.7) & 339 (83.7) & $324(80.0)$ & 331 (81.7) & $369(91.1)$ & 351 (86.7) & $285(70.4)$ \\
\hline no & $26(6.4)$ & $13(3.2)$ & $13(3.2)$ & $45(11.1)$ & 24 (5.9) & $11(2.7)$ & $25(6.2)$ & $61(15.1)$ \\
\hline not sure & $32(7.9)$ & 45 (11.1) & $53(13.1)$ & $36(8.9)$ & $50(12.3)$ & $25(6.2)$ & $29(7.2)$ & 59 (14.6) \\
\hline
\end{tabular}

*Multiple responses were possible; ** Percentage within the group.

Pharmacists' perceived barriers and their suggestions to encourage reporting of $A D R s$

Most pharmacists who participated in this study consider obstacles to reporting ADRs. 78.8\% acknowledged that there is little knowledge of PV among pharmacists. As obstacles in reporting are perceived lack of time (61.5\% of respondents) and lack of infrastructure (47.7\% of respondents). $65.2 \%$ of pharmacists declared no reference materials, and $37.8 \%$ claimed limited time to report. $35.1 \%$ were not sure about the certainty about ADR (Table 7).

There were statistically significant differences between the workplace of pharmacists and their responses. For example, $42.18 \%$ and $38.54 \%$ of community pharmacists responded that they have limited time for reporting and were unsure of ADR's certainty, respectively, compared to other subgroups (Table 8).

Regarding improvements of ADRs reporting participating pharmacists gave numerous suggestions for ways to encourage pharmacists to report ADRs. Most pharmacists suggested that there is a need to raise pharmacists' awareness toward PV and ADR reporting through educational training of pharmacists (87.4\%), information campaigns $(78.3 \%)$, and being updated with the latest reference materials $(83.7 \%)$. Improvement of communication with other healthcare professionals $(86.2 \%)$ and the PV Department $(84.2 \%)$ was also positively stated by respondents. Other participants' suggestions were to increase staff $(64.2 \%)$ at their workplace and improve infrastructure (59.3\%) (Table 9).

There were statistically significant differences regarding the working experience of participating pharmacists. As presented in Table 10, pharmacists with longer working experience considered it was necessary to improve the infrastructure compared to younger pharmacists.

Table 5. Response differences between pharmacists depending on their work experience

\begin{tabular}{|c|c|c|c|c|}
\hline \multirow{3}{*}{ Questions } & \multicolumn{4}{|c|}{ Experience } \\
\hline & Less than 1 year & $1-5$ years & $6-10$ years & Over 10 years \\
\hline & $\mathrm{N}(\%)^{* *}$ & $\mathrm{~N}(\%)$ & $\mathrm{N}(\%)$ & $\mathrm{N}(\%)$ \\
\hline $\mathrm{PV}$ to include in curricula & $71(94.7)$ & $79(84.9)$ & $110(84.6)$ & $87(81.3)$ \\
\hline $\begin{array}{l}\text { Community and hospital pharmacist should } \\
\text { be the first contact point for reporting ADR }\end{array}$ & $63(84)$ & $67(72)$ & $106(81.5)$ & $88(82.2)$ \\
\hline If trained we'll practice PV & $68(90.7)$ & $66(71)$ & $110(84.6)$ & $87(81.3)$ \\
\hline
\end{tabular}

\footnotetext{
Answer: yes, $p<0.05$
} 
Table 6. Pharmacists' practice regarding pharmacovigilance and ADR reporting*

\begin{tabular}{lllllll}
\hline \hline & $\begin{array}{l}\text { Internet/ } \\
\text { webpages }\end{array}$ & $\begin{array}{l}\text { Reference } \\
\text { books }\end{array}$ & $\begin{array}{l}\text { Medical } \\
\text { journals }\end{array}$ & $\begin{array}{l}\text { Medical/ Sales } \\
\text { representatives }\end{array}$ & $\begin{array}{l}\text { Patient information } \\
\text { leaflets/drug } \\
\text { information leaflets }\end{array}$ & KMA bulletins \\
& $\mathrm{N}(\%)^{* *}$ & $\mathrm{~N}(\%)$ & $\mathrm{N}(\%)$ & $\mathrm{N}(\%)$ & $\begin{array}{l}\mathrm{N}(\%) \\
\end{array}$ \\
& $313(77.3)$ & $284(70.1)$ & $186(45.9)$ & $158(39.0)$ & $297(73.3)$ & $249(61.5)$ \\
nes & $38(9.4)$ & $53(13.1)$ & $106(26.2)$ & $139(34.3)$ & $34(8.4)$ & $61(15.1)$ \\
not sure & $54(13.3)$ & $68(16.8)$ & $113(27.9)$ & $108(26.7)$ & $74(18.3)$ & $95(23.5)$
\end{tabular}

* Multiple responses were possible; ** Percentage within the group.

\section{Discussion}

To our knowledge, until now in Kosovo, there have been no studies that evaluated pharmacists' knowledge, attitudes and practice regarding $\mathrm{PV}$ and the ADR reporting process, and this is the first one in this field. The results show that they have insufficient knowledge about the concept of PV and ADR reporting. In general, pharmacists' knowledge regarding PV and the ADR reporting process was significantly affected by their workplace. Pharmacists of other fields of pharmacy not related to community pharmacy showed better knowledge compared to community pharmacists.

Regarding pharmacists' attitudes towards ADRs reporting, most pharmacists (between $70.4 \%$ to $91.1 \%$ ) agree that reporting is one of their essential roles, and they should report, and PV should be included in curricula. They are aware that patients will benefit from reporting ADRs, and they showed their readiness to practice PV if they receive training. Pharmacists' demonstrated positive attitude is similar to other studies (Alshammari et al., 2015; Belton, 1997; Granas et al., 2007; Lee et al., 1994; Suyagh et al., 2015; Toklu and Uysal, 2008). However, as emphasized in a study by Herdeiro et al. (2006), attitudes are potentially modifiable variables, and the educational programs can influence ADRs reporting behavior positively (Granas et al., 2007).
More than half of the pharmacists in the study declared that they receive patient complaints, but there is still a small number of received ADR reports with low quality submitted by pharmacists. The problem of underreporting is a global problem among pharmacists and other healthcare professionals (Generali et al., 1995; Granas et al., 2007; Green et al., 2001; Herdeiro et al., 2005; Herdeiro et al., 2006; Lee et al., 1994; Suyagh et al., 2015; Sweis and Wong., 2000; Toklu and Uysal., 2008).

In Kosovo, the main barriers for under-reporting the pharmacists have been considered their insufficient knowledge of PV. However, as other perceived barriers, they stated lack of staff, limited time, and uncertainty in assessing drug-ADR relatedness. These findings were similar to other published studies (Alomar et al., 2020; Hasford et al., 2002; Vessal et al., 2009).

Pharmacists' suggestions to encourage reporting were improvement of communication with the PV Department. In addition, they considered necessary as well training, information campaigns, $\mathrm{PV}$ in the medical education curricula, and the latest reference materials.

As described in previous studies optimizing knowledge, attitude, and practices (KAP) about PV is vital in formulating strategies to encourage ADR reporting (Alsaleh et al., 2017; Ahmad et al., 2013; Suyagh et al., 2015) and thus improving national pharmacovigilance systems.

Table 7. Barriers to reporting ADRs by pharmacists*

\begin{tabular}{|c|c|c|c|c|c|c|}
\hline & $\begin{array}{l}\text { Lack of } \\
\text { staff } \\
\mathrm{N}(\%)^{* *}\end{array}$ & $\begin{array}{l}\text { No } \\
\text { infrastructure } \\
\mathrm{N}(\%)\end{array}$ & $\begin{array}{l}\text { Little } \\
\text { knowledge } \\
\mathrm{N}(\%)\end{array}$ & $\begin{array}{l}\text { No reference } \\
\text { materials } \\
\mathrm{N}(\%)\end{array}$ & $\begin{array}{l}\text { Limited time } \\
\mathrm{N}(\%)\end{array}$ & $\begin{array}{l}\text { Not sure if ADR } \\
\mathrm{N}(\%)\end{array}$ \\
\hline yes & $249(61.5)$ & $193(47.7)$ & $319(78.8)$ & $264(65.2)$ & $153(37.8)$ & $138(34.1)$ \\
\hline no & $99(24.4)$ & $130(32.1)$ & $49(12.1)$ & 75 (18.5) & $153(37.8)$ & $125(30.9)$ \\
\hline not sure & $57(14.1)$ & $82(20.2)$ & $37(9.1)$ & 66 (16.3) & 99 (24.4) & $142(35.1)$ \\
\hline
\end{tabular}

* Multiple responses were possible; ** Percentage within the group. 
Table 8. Response differences between pharmacists depending on their workplace

\section{Workplace}

Community pharmacists

$$
\mathrm{N}(\%) * * *
$$

Questions

Limited time *

$116(42.18)$

$37(28.5)$

Not sure if ADR **

$106(38.54)$

$56(27.7)$

Answer: * yes; $* *$ not sure; $p<0.05 ; * * *$ Percentage within the group

Table 9. Recommendations to encourage reporting of ADRs by pharmacists*

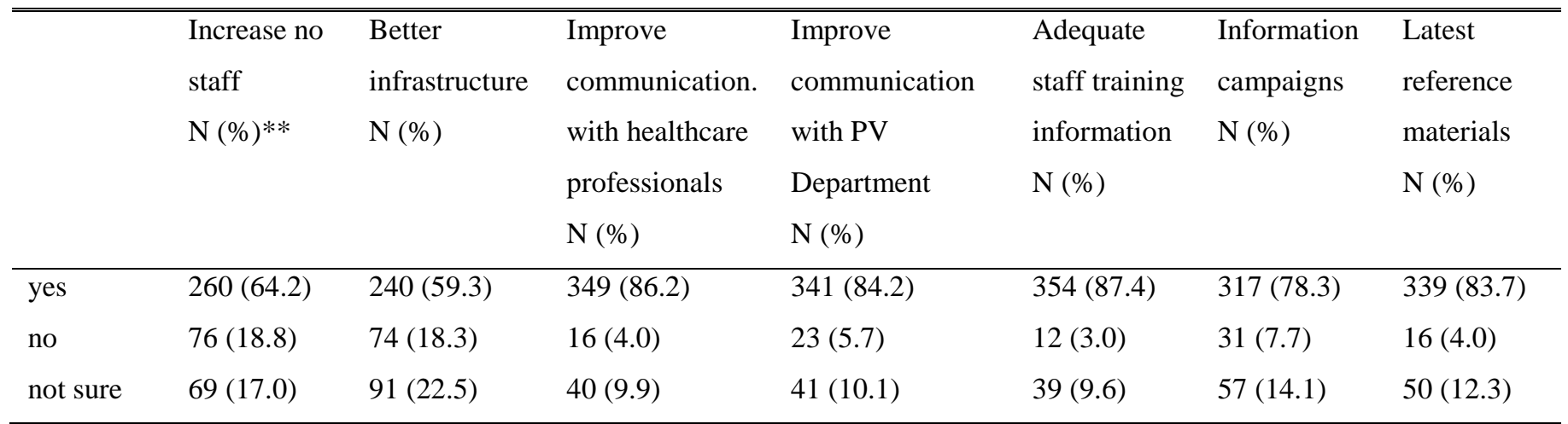

* Multiple responses were possible; ** Percentage within the group.

Table 10. Response differences between pharmacists depending on their work experience

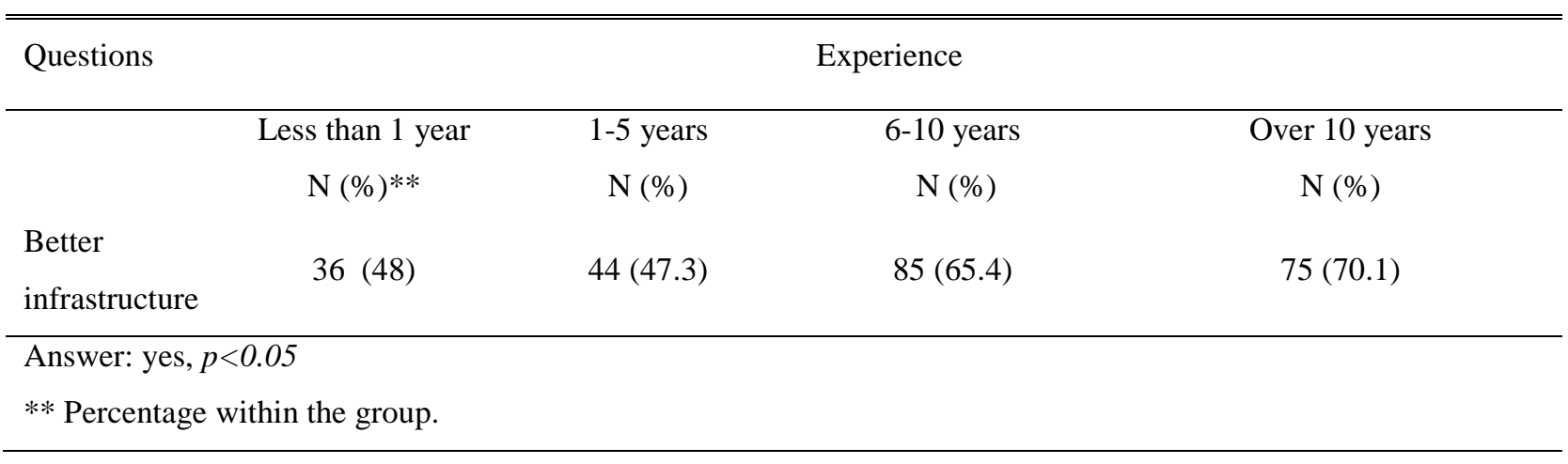




\section{Conclusion}

Current evidence shows that pharmacists are not implementing $\mathrm{PV}$ in Kosovo due to insufficient knowledge about PV and the ADRs reporting process. In order to improve the current situation is necessary to intensify communication among all stakeholders involved in PV. It is essential to prepare the draft of the strategic plan on training and educational programs to increase knowledge and awareness of the importance of pharmacists' ADRs reporting. ADR reporting system is an essential part of drug safety, and the participation of pharmacists and other healthcare professionals is essential for the successful functioning of the PV system.

\section{References}

Ahmad, A., Patel, I., Balkrishnan, R., Mohanta, G.P., Manna, P.K., 2013. An evaluation of knowledge, attitude and practice of Indian pharmacists towards adverse drug reaction reporting: A pilot study. Perspect. Clin. Res. 4(4), 204-210. Available at: https://doi.org/10.4103/22293485.120168.

Ali, M.D., Hassan, Y.A., Ahmad, A., Alaqel, O., Al-Harbi, H., Al-Suhaimi, N.M., 2018. Knowledge, Practice and Attitudes Toward Pharmacovigilance and Adverse Drug Reactions Reporting Process Among Health Care Providers in Dammam, Saudi Arabia. Curr. Drug. Saf. 13(1), 21-25. Available at:

https://doi.org/10.2174/1574886313666171218123802.

Almandil N.B., 2016. Healthcare professionals' awareness and knowledge of adverse drug reactions and pharmacovigilance. Saudi. Med. J. 37(12), 1359-1364. Avaialable at: https://doi.org/10.15537/smj.2016.12.17059.

Alomar, M., Tawfiq, A.M., Hassan, N., Palaian, S., 2020. Post marketing surveillance of suspected adverse drug reactions through spontaneous reporting: current status, challenges and the future. Ther. Adv. Drug. Saf. 11, 2042098620938595. Available at: https://doi.org/10.1177/2042098620938595.

Alsaleh, F.M., Alzaid, S.W., Abahussain, E.A., Bayoud, T., Lemay, J., 2017. Knowledge, attitude and practices of pharmacovigilance and adverse drug reaction reporting among pharmacists working in secondary and tertiary governmental hospitals in Kuwait. Saudi. Pharm. J. 25(6), 830-837. Available at: https://doi.org/10.1016/j.jsps.2016.12.004.

Alshammari, T.M., Alamri, K.K., Ghawa, Y.A., Alohali, N.F., Abualkol, S.A., Aljadhey, H.S., 2015. Knowledge and attitude of health-care professionals in hospitals towards pharmacovigilance in Saudi Arabia. Int. J. Clin. Pharm. 37(6), 1104-1110. https://doi.org/10.1007/s11096015-0165-5.

Amedome, S.N., Dadson, B.A., 2017. Pharmacovigilance Practices: Knowledge and Attitudes among Healthcare Professionals at the Volta Regional Hospital of Ghana. J. Pharmacovigil. 5(3). Available at: https://doi.org/10.4172/2329-6887.1000229.

Belton K.J. 1997. Attitude survey of adverse drug-reaction reporting by health care professionals across the European
Union. The European Pharmacovigilance Research Group. Eur. J. Clin. Pharmacol. 52(6), 423-427. Available at: https://doi.org/10.1007/s002280050314.

Elshafie, S., Zaghloul, I., Roberti, A.M., 2018. Pharmacovigilance in developing countries (part I): importance and challenges. Int. J. Clin. Pharm. 40(4), 758763. Available at: https://doi.org/10.1007/s11096-0170570-z.

FIP (International Pharmaceutical Federation). FIP statement of policy: the role of the pharmacist in pharmacovigilance, 2006. Available at: https://www.fip.org/file/1464 (Last accessed: June 8, 2021).

Generali, J.A., Danish, M.A., Rosenbaum, S.E., 1995. Knowledge of and attitudes about adverse drug reaction reporting among Rhode Island pharmacists. Ann. Pharmacother. 29(4), 365-369. Available at: https://doi.org/10.1177/106002809502900404.

Granas, A.G., Buajordet, M., Stenberg-Nilsen, H., Harg, P., Horn, A.M., 2007. Pharmacists' attitudes towards the reporting of suspected adverse drug reactions in Norway. Pharmacoepidemiol. Drug. Saf. 16(4), 429-434. Available at: https://doi.org/10.1002/pds.1298.

Green, C.F., Mottram, D.R., Rowe, P.H., Pirmohamed, M., 2001. Attitudes and knowledge of hospital pharmacists to adverse drug reaction reporting. Br. J. Clin. Pharmacol. 51(1), 81-86. Available at: https://doi.org/10.1046/j.13652125.2001.01306.x.

Hasford, J., Goettler, M., Munter, K.H., Müller-Oerlinghausen, B., 2002. Physicians' knowledge and attitudes regarding the spontaneous reporting system for adverse drug reactions. J. Clin. Epidemiol. 55(9), 945-950. Available at: https://doi.org/10.1016/s0895-4356(02)00450-x.

Herdeiro, M.T., Figueiras, A., Polónia, J., Gestal-Otero, J.J., 2005. Physicians' attitudes and adverse drug reaction reporting: a case-control study in Portugal. Drug Saf. 28(9), 825-833. Available at: https://doi.org/10.2165/00002018200528090-00007.

Herdeiro, MT., Figueiras, A., Polónia, J., Gestal-Otero, J.J., 2006. Influence of pharmacists' attitudes on adverse drug reaction reporting: a case-control study in Portugal. Drug Saf. 29(4), 331-340. Available at: https://doi.org/10.2165/00002018-200629040-00004.

Khalili, H., Mohebbi, N., Hendoiee, N., Keshtkar, A.A., DashtiKhavidaki, S., 2012. Improvement of knowledge, attitude and perception of healthcare workers about ADR, a preand post-clinical pharmacists' interventional study. BMJ open 2(1), e000367. Available at: https://doi.org/10.1136/bmjopen-2011-000367.

Kosovo Medicines Agency. Available at: https://akppm.rksgov.net/ (Last accessed: March 14, 2021)

Lee, K.K., Chan, T.Y., Raymond, K., Critchley, J.A., 1994. Pharmacists' attitudes toward adverse drug reaction reporting in Hong Kong. Ann. Pharmacother. 28(12), 1400-1403. Available at: https://doi.org/10.1177/106002809402801213.

Li, R., Curtain, C., Bereznicki, L., Zaidi, S., 2018. Community pharmacists' knowledge and perspectives of reporting adverse drug reactions in Australia: a cross-sectional survey. Int. J. Clin. Pharm. 40(4), 878-889. Available at: https://doi.org/10.1007/s11096-018-0700-2.

Najafi, S., 2018. Importance of Pharmacovigilance and the Role of Healthcare Professionals. J. Pharmacovigil. 6, 252. Available at: 10.4172/2329-6887.1000252.

Макед. фарм. билт., 67 (1) 67 - 77 (2021) 
Nisa, Z.U., Zafar, A., Sher, F., 2018. Assessment of knowledge, attitude and practice of adverse drug reaction reporting among healthcare professionals in secondary and tertiary hospitals in the capital of Pakistan. Saudi. Pharm. J. 26(4), 453-461. Available at: https://doi.org/10.1016/j.jsps.2018.02.014.

Olsson, S., Pal, S.N., Stergachis, A., Couper, M., 2010. Pharmacovigilance activities in 55 low- and middleincome countries: a questionnaire-based analysis. Drug Saf. 33(8), 689-703. Available at: https://doi.org/10.2165/11536390-000000000-00000.

Oreagba, I.A., Ogunleye, O.J., Olayemi, S.O., 2011. The knowledge, perceptions and practice of pharmacovigilance amongst community pharmacists in Lagos state, south west Nigeria. Pharmacoepidemiol. Drug Saf. 20(1), 3035. Available at: https://doi.org/10.1002/pds.2021.

Prakasam, A., Nidamanuri, A., Kumar, S., 2012. Knowledge, perception and practice of pharmacovigilance among community pharmacists in South India. Pharm. Pract. (Granada). 10(4), 222-226. Available at: https://doi.org/10.4321/s1886-36552012000400006.

Su, C., Ji, H., Su, Y., 2010. Hospital pharmacists' knowledge and opinions regarding adverse drug reaction reporting in Northern China. Pharmacoepidemiol. Drug. Saf. 19(3), 217-222. https://doi.org/10.1002/pds.1792.

Suyagh, M., Farah, D., Abu Farha, R., 2015. Pharmacist's knowledge, practice and attitudes toward pharmacovigilance and adverse drug reactions reporting process. Saudi. Pharm J. 23(2), 147-153. Available at: https://doi.org/10.1016/j.jsps.2014.07.001.

Sweis, D., Wong, I.C., 2000. A survey on factors that could affect adverse drug reaction reporting according to hospital pharmacists in Great Britain. Drug Saf. 23(2),
165-172. Available at: https://doi.org/10.2165/00002018200023020-00006.

Toklu, H.Z., Uysal, M.K., 2008. The knowledge and attitude of the Turkish community pharmacists toward pharmacovigilance in the Kadikoy district of Istanbul. Pharm. World. Sci. 30(5), 556-562. https://doi.org/10.1007/s11096-008-9209-4.

The World Bank. The World Bank in Kosovo. Available at: https://www.worldbank.org/en/country/kosovo/overview. (Last accessed: December 9, 2019).

Vessal, G., Mardani, Z., Mollai, M., 2009. Knowledge, attitudes, and perceptions of pharmacists to adverse drug reaction reporting in Iran. Pharm. World. Sci. 31(2), 183187. Available at: https://doi.org/10.1007/s11096-0089276-6.

Wilson, R.M., Michel, P., Olsen, S., Gibberd, R.W., Vincent, C., El-Assady, R., Rasslan, O., Qsous, S., Macharia, W.M., Sahel, A., Whittaker, S., Abdo-Ali, M., Letaief, M., Ahmed, N.A., Abdellatif, A., Larizgoitia, I., WHO Patient Safety EMRO/AFRO Working Group, 2012. Patient safety in developing countries: retrospective estimation of scale and nature of harm to patients in hospital. BMJ (Clinical research ed.), 344, e832. Available at: https://doi.org/10.1136/bmj.e832.

WHO, Essential medicines and health products. Pharmacovigilance. Available at: https://www.who.int/medicines/areas/quality_safety/safety _efficacy/pharmvigi/en/. (Last accessed: June 17, 2019).

WHO, 2002. The importance of pharmacovigilance.Available at: https://apps.who.int/iris/handle/10665/42493.

WHO, 2004. Pharmacovigilance: ensuring the safe use of medicines. Available at: https://apps.who.int/iris/handle/10665/68782. 


\title{
Познавање, став и пракса на фармацевтите за фармаковигиланца и процесот на пријавување на несакани реакции на лекови: пресечна студија во Косово
}

\author{
Селвете Шулета - Ќехаја ${ }^{1}$, Зоран Стерјев²*, Љубица Шутуркова ${ }^{2}$, \\ Александра Капедановска ${ }^{2}$, Зорица Наумовска ${ }^{2}$ Виртуте Красниќи ${ }^{3}$, \\ Ерблин Елези ${ }^{4}$ \\ ${ }^{1}$ Алма Матер Еуропеа Кампус Колеи „Резонанияа“, блок „Ветерник“, \\ 10000 Приштина, Косово \\ ${ }^{2}$ Универзитет „Св. Кирил и Методиј“, Фармачевтски факултет, \\ Мајка Тереза 47, 1000 Скопје, Република Северна Македонија \\ ${ }^{3}$ Косовска агенција за лекови, Рети и спиталит (QKUK), 10000 Приштина, Косово \\ ${ }^{4}$ Централна фармаиија - Универзитетски клинички иентар, 10000 Приштина, Косово
}

Клучни зборови: фармаковигиланца, несакана реакција на лекот, познавање, став, пракса, фармацевти, Косово

Фармаковигиланцата (PV) и следењето на безбедноста на лековите имаат суштинска улога во заштитата на јавното здравје. Пресечната студија го оцени знаењето, ставот и праксата на фармацевтот кон PV и пријавувањето на несакани реакции на лекови (ADR). Структуираниот валидиран прашалник беше дистрибуиран до 550 случајно избрани фармацевти во целиот косовски регион. На прашалникот одговориле 405 од 550 фармацевти. Повеќето фармацевти немаат доволно знаење за фармаковигиланцата и процесот на пријавување на ADR. Главните причини за недоволно пријавување се мало познавање на фармаковигиланцата и процесот на пријавување, недостаток на време и недостаток на инфраструктура. Сепак, фармацевтите покажаа позитивен став и изјавија дека би практикувале фармаковигиланца доколку добијат обука. Постои потреба да се интензивира комуникацијата меѓу сите засегнати страни вклучени во PV. Покрај тоа, потребна е постојана обука и едукација за да се зголеми свеста и знаењето на фармацевтот за PV и нивното учество во процесот на пријавување на ADR. 
